\title{
POLITIK PENYETARAAN DAYAH DI ACEH
}

\author{
Oleh : \\ Al Muhajir Muslimin*
}

\begin{abstract}
Abstrak
Hubungan antara lembaga pendidikan dan politik bukan sekadar hubungan saling mempengaruhi, tetapi juga hubungan fungsional. Lembaga-lembaga dan proses pendidikan berperan penting dalam membentuk perilaku politik masyarakat di negara atau daerah. Dayah sebagai lembaga pendidikan tertua di Aceh, telah memainkan perannya dalam membangun negeri ini, mengalami pasang surut dalam legalitasnya. Pasca Tsunami dan MOU Helsinki, dayah "meminta hak" agar tidak lagi dianak tirikan dengan lembaga pendidikan lain yang ada di Aceh. Hasil usahanya, Dayah akhirnya mendapatkan legalitas dari Pemerintah Aceh sebagai lembaga Formal yang disejajarkan dengan pendidikan formal lainya, serta alumninya bisa diterima dibeberapa instansi pemerintah dan swasta, walaupun dengan beberapa persyaratan yang telah ditetapkan oleh Pemerintah Aceh yang dibentuk lewat Badan Pembinaan Pendidikan Dayah Aceh (BPPDA). Fenomena sekarang telah menunjukkan bahwa Dayah dan Pemerintah Aceh telah memiliki simbiosis mutualisme antara keduanya.
\end{abstract}

Kata Kunci: Politik, Penyetaraan, Dayah, Aceh

\section{Pendahuluan}

Pendidikan dan politik adalah dua elemen penting dalam sistem sosial politik disetiap negara, baik negara maju maupun berkembang. Keduanya sering dilihat sebagai bagian-bagian yang terpisah, yang satu sama lain tidak memiliki hubungan apa-apa. Padahal keduanya bahu-membahu dalam proses pembentukan karakteristik masyarakat di suatu negara. Lebih

* STAIN Malikussaleh Lhokseumawe. 
dari itu, keduanya satu sama lain saling menunjang dan saling mengisi. Lembaga-lembaga dan proses pendidikan berperan penting dalam membentuk perilaku politik masyarakat di negara tersebut. Ada hubungan erat dan dinamis antara pendidikan dan politik disetiap negara. Hubungan tersebut adalah realitas empiris yang telah terjadi sejak awal perkembangan peradaban manusia dan menjadi perhatian para ilmuwan. ${ }^{1}$

Mukaddimah yang penulis awali pada paragraf tersebut diatas, betapa bahwa hubungan pendidikan dan politik dalam skala makro yakni negara ternyata tidak bisa dipisahkan. Berangkat dari konsep makro tersebut di atas, ternyata untuk tingkat mikro juga mengalami hal yang sama di mana hubungan pendidikan dan politik di tingkat daerah saling mempengaruhi, hal ini terbukti dengan kebijakan politik dari pemerintah daerah yang dipengaruhi oleh "atmosfir" pendidikan suatu daerah. Aceh $^{2}$ misalnya, seiring perkembangan waktu dan IPTEK, lembaga pendidikan tertua di Aceh yakni Dayah ${ }^{3}$ telah melakukan "invasi" keberbagai aspek kehidupan masyarakat Aceh, sehingga banyak alumni Dayah yang mengisi tempattempat strategis di pemerintahan maupun dilembaga-lembaga swasta.

Eksistensi Dayah khususnya di Aceh menurut perkiraan James T. Siegel sebagaimana yang dikutip oleh Hamdiah telah

${ }^{1}$ Muhammad Sirozi, Politik Pendidikan (Jakarta: Raja Grafindo Persada, 2010), hal. 1.

${ }^{2}$ Aceh adalah sebuah daerah yang terletak di ujung pulau sumatera paling barat Indonesia. Daerah ini berbatasan dengan teluk benggala disebelah utara, samudra hindia disebelah barat, selat malaka disebelah timur, dan sumatera utara di sebelah tenggara dan selatan. Lihat, Rusdi Sufi dan Agus Budi Wibowo, Pendidikan Di Aceh dari Masa ke Masa (Banda Aceh: Badan Perpustakaan Provinsi NAD, 2009) hal. 5.

3 Dayah, demikian sebutan masyarakat Aceh kepada Pesantren, masyarakat lebih mengenal istilah Dayah ketimbang Pesantren. Penyebutan nama Dayah untuk pesantren merupakan sebutan "warisan" yang telah ditinggalkan sejak dulu. Dayah di Aceh dikelompokkan secara umum ada dua yaitu Dayah Tradisional (Salafiyah) dan Dayah Terpadu. Dalam tulisan ini Dayah yang menjadi penekanan pembahasannya adalah Dayah Salafiyah. Sedangkan Dayah modern/terpadu sudah dikategorikan dalam lembaga formal, disana ada MA dan MTs, sehingga Dayah modern/terpadu tidak lagi menjadi "polemik" bagi masyarakat dan Pemerintah Aceh. 
ada semenjak kesultanan dan turut mewarnai kehidupan masyarakat secara menyeluruh dan memainkan fungsi sosial, khususnya dalam disiplin ilmu agama. Masyarakat Aceh terutama anak-anak mudanya kebanyakan meudagang (nyantri), merantau untuk mendapatkan bekal pengetahuan. ${ }^{4}$

Dayah di Aceh telah mampu menunjukkan partisipasi aktifnya bersama-sama elemen masyarakat termasuk pemerintah dalam menyukseskan program-program pembangunan, terlebih dalam hal kehidupan keagamaan dan pencerdasan anak bangsa. Pergulatan literatur sejarah dan dinamika sosial secara dialektik membuat Dayah mempunyai kesadaran dan konsen untuk ikut mengawasi proses perjalanan bangsa sesuai dengan cita-cita agama dan masyarakat secara universal. ${ }^{5}$

Dalam lintasan sejarah, eksistensi Dayah menjadi istimewa karena ia menjadi pendidikan alternatif (penyeimbang) dari pendidikan yang dikembangkan oleh kaum kolonial (Barat) yang hanya bisa dinikmati oleh segelintir orang. Dayah menjadi tempat berlabuh umat Islam yang tersingkir secara budaya (pendidikan) akibat perlakuan diskriminatif penjajah. Kini perkembangan Dayah dengan sistem pendidikannya mampu mensejajarkan diri dengan pendidikan lain pada umumnya. Kenyataan ini menjadi aset yang luar biasa baik bagi perkembangan pendidikan Dayah maupun pendidikan Aceh bahkan nasional pada masa sekarang dan masa yang akan datang. Dari sana diharapkan tumbuh kaum intelektual yang berwawasan luas dengan landasan spiritual yang kuat.

\section{Permasalahan}

Pendidikan pada dasarnya selalu bersinggungan dengan "kekuasaan" dalam hal ini kekuasaan bisa dipahami sebagai salah satu aspek kehidupan masyarakat yang berkaitan dengan persaingan antar kelompok dalam memperebutkan pengaruh baik diluar maupun didalam kawasan pendidikan itu sendiri, serta bisa dimengerti sebagai kekuasaan negara yang wilayah

${ }^{4}$ Hamdiah M. Latif, Tradisi dan Vitalitas Dayah (Kesempatan dan Tantangan), Jurnal Ilmiah DIDAKTIKA, Vol.8, No.2, 2007, hal. 1.

${ }^{5}$ Mashuri, Dinamika Sistem Pendidikan Islam Di Dayah, Jurnal Ilmiah DIDAKTIKA, Vol. 13, No. 2, 2013, hal. 263. 
jangkauannya mencakup banyak bidang termasuk kekuasaan negara dalam pendidikan. ${ }^{6}$ Persinggungan antara keduanya tersebut menurut Edward Steven dan George $\mathrm{H}$ Wood, sebernarnya bersumber dari adanya "system of beliefs" yang sama. Dengan "system of beliefs" ini suatu cita-cita yang ideal masyarakat dan pendidikan hendak dibangun, dalam pengertian sederhana "system of beliefs" ini disebut dengan ideologi.

Dayah sebagai sebuah lembaga pendidikan Islam sangat berperan langsung dalam mendesign perubahan masyarakat, menjadi tumpuan dan solusi bagi setiap situasi kondisi yang melanda masyarakat sekitarnya. Indikator dari agument ini dapat dilihat dari perubahan tujuan pendidikan, komponen-komponen kuriklum dan pengajaran yang disesuaikan dengan kebutuhan tiap-tiap keadaan masyarakat Aceh dalam sejarah. ${ }^{8}$

Dalam menjalankan operasionalnya, Dayah mengalami berbagai problematika, mulai dari kepemimpinan Dayah, santri, tenaga pendidik, kurikulum, keuangan, sarana dan prasarana, sampai dengan masalah kelulusan santrinya. ${ }^{9}$ Dayah sebagai lembaga Pendidikan tradisional memiliki asumsi miring dalam sebahagian pola pikir masyarakat Aceh, asumsi miring itu adalah adanya anggapan bahwa jak beut hana masa depan (Menuntut Ilmu di Dayah tidak memiliki prospek masa depan). Asumsi ini bermakna bahwa Dayah sebagai lembaga pendidikan belum mampu memberikan jaminan masa depan yang cerah kepada para alumninya, seperti halnya lembaga pendidikan lain semisal Perguruan Tinggi.

Pada bagian lain, Dayah dijadikan "bengkel" moral anak-anak yang memiliki akhlak yang tidak baik. Sehingga

${ }^{6}$ Arif Rohman, Politik Ideologi Pendidikan (Yogyakarta: LaksBang Mediatama, 2009), hal. 3.

7 Edward Steven and George H. Wood, Justice, Idiologi, And Education: An Introduction To The Social Fundation Of Education (New York: Random House, 1987), hal. 149.

${ }^{8}$ Saifuddin Dhuhri, DAYAH DALAM TIGA PHASE PERKEMBANGAN (Menelaah Pendidikan Berbasis Perubahan Sosial yang telah Punah), Jurnal SARWAH, Vol, IX, No. 1, 2011, hal. 166.

${ }^{9}$ Almuhajir, Manajemen Dayah: Realita, Problematika, dan Cita-cita, Jurnal TRIBAKTI, Vol. 23, No. 2, 2012, hal. 187. 
asumsi sebagian masyarakat jika ada orang tua yang mengantarkan anaknya ke Dayah, berarti anaknya itu bermasalah (akhlak). Di tambah lagi kesenjangan bantuan dana pendidikan yang hanya diperuntukan kepada lembaga formal saja. Dayah dengan kemandirian financialnya, dilapangan (penulis menyebutkan) akan kita dapatkan Dayah bonafit ${ }^{10}$, Dayah stagnan ${ }^{11}$, dan Dayah hidup segan mati tak mau ${ }^{12}$.

Berangkat dari fenomena ini, berawal dari era reformasi, era "Gerakan Aceh Merdeka", dan pasca UUPA, para perangkat Dayah angkat bicara tentang kondisi pendidikan di Aceh. Mengapa ketika berbicara tanggung jawab moral generasi Aceh diberikan beban kepada Dayah, sedangkan ketika menikmati "pembangunan" daerah, Dayah tidak diikut sertakan, sehingga terjadi anak tiri dalam kebijakan pendidikan di Aceh.

Atas sikap yang ditunjukkan oleh para perangkat Dayah tersebut, akhirnya Pemerintah Aceh mengakomodir keinginan Dayah untuk dimasukkan dalam berbagai kebijakan pendidikan (dengan berbagai syarat), diantaranya adalah alumni Dayah boleh melanjutkan ke lembaga formal berikutnya (PTAI ${ }^{13}$, dimasukkannya bantuan pendidikan untuk Dayah dengan dibentuknya sebuah lembaga yang khusus menangani Dayah yaitu Badan Pembinaan Pendidikan Dayah Aceh (BPPDA), serta dibolehkannya alumni Dayah untuk masuk menjadi anggota militer (Polri /TNI) ${ }^{14}$.

10 Dayah yang memiliki hubungan dengan penguasa/pemerintah, dengan mudah mendapatkan bantuan financial.

${ }^{11}$ Dayah yang tidak memiliki hubungan dengan penguasa, walaupun ada, tetapi bukanlah dengan orang-orang yang terpenting dalam pemerintahan, serta donatur bebas.

12 Dayah yang sama sekali tidak memiliki hubungan dengan pemerintah, roda pendidikannya hanya mengandalkan sumbangan santri.

${ }^{13}$ Perguruan Tinggi Agama Islam (PTAI) yang dibenarkan adalah prodi/jurusan/fakultas yang linear dengan kajian keilmuan ketika ada di Dayah, seperti Bahasa Arab, PAI, Ushuluddin, Dakwah, dan Syariah.

14 Kepala Staf Kodam (Kasdam) Iskandar Muda, Brigjen TNI Iskandar M Sahil mengatakan, Tentara Nasional Indonesia (TNI) memberi kesempatan luas kepada lulusan Dayah (pesantren) di Aceh untuk menjadi tamtama TNI. Bahkan dalam rekrutmennya akan diberikan jatah yang lebih besar untuk putra-putra Aceh. Hal itu diungkapkan Kasdam Iskandar Muda 
Di tengah keinginan berbagai pihak untuk melakukan legalisasi pendidikan Dayah agar setara dengan pendidikan lainnya, gayung bersambut, pemerintah akhirnya mengeluarkan aturan yang menghapus diskriminasi Dayah dalam sistem pendidikan nasional, adalah UU nomor 20 tahun 2003 sebagai cikal bakal payung hukum yang mengakui Dayah sebagai salah satu lembaga pendidikan, ditambah lagi dengan Peraturan Pemerintah (PP) Nomor 55 Tahun 2007 tentang Pendidikan Agama dan Pendidikan Keagamaan yang semakin memperkuat posisi Dayah.

\section{Pembahasan}

\section{Dayah dalam lintasan sejarah}

Di Aceh, istilah untuk lembaga yang dikenal dengan sebutan pondok pesantren di Jawa dan berbagai tempat lainnya di Indonesia adalah Dayah (Siegel, 1969: 48). Kata Dayah, juga sering diucapkan dengan sebutan "deah" oleh sebagian orang Aceh, terutama di Ace Besar. ${ }^{15}$

Terminologi ini berasal dari kata bahasa Arab yaitu Zawiyah, yang berarti sebuah sudut, pojok atau kegiatan dari suatu tempat atau bangunan. Dalam perkembangannya, setelah mengalami adaptasi kultural kata zawiyah mengalami perubahan dialek dalam pengucapan orang Aceh, yaitu perubahan dari kata zawiyah menjadi Dayah. Sebab di Aceh dalam bahasa seharihari sering terjadi pertukaran dialek huruf $\mathrm{Z}$ menjadi huruf $\mathrm{D} .{ }^{16}$ Secara genealogis, kata zawiyah ini pertama kali digunakan untuk penyebutan sudut mesjid Madinah tatkala Nabi Muhammad saw. berdakwah pada masa awal Islam. ${ }^{17}$

mewakili Pangdam saat presentasi para Rapat Koordinasi Majelis Permusyawaratan Ulama (MPU) Aceh di Hotel Permata Hati, Aceh Besar, Sabtu, 15/9/2012. Lihat, http://bangun-aceh.blogspot.com/2012/09/tentaradari-alumni-Dayah-mengapa-tidak.html, diakses tanggal 12 Juni 2014.

${ }^{15}$ C. Snouck Hurgronje, The Atjehnese, A.W.S. O'Sullivan (terj.), Vol.I, (Leiden: J.Brill, 1906), hal. 63.

${ }^{16}$ Rusdi Sufi, Tgk. Hasan Krueng Kalee dan Teuku Nyak Arief, Profil Ulama dan Umara Aceh (Banda Aceh: Badan Perpustakaan Provinsi NAD, 2006), hal. 73.

${ }^{17}$ Mohd. Basyah Haspy, Appresiasi terhadap Tradisi Dayah: Suatu Tinjauan terhadap Tata Krama dan Kehidupan Dayah, (Banda Aceh: Panitia 
Perkembangan Dayah di Aceh bila ditinjau dari beberapa penggalan sejarah perjalannya mengalami resonansi, sesuai dengan kondisi yang terjadi pada saat itu. Berikut ini akan diuraikan sekilas perjalannya, yang meliputi Dayah sebelum perang, Dayah pada masa perjuangan, Dayah pada masa kemerdekaan dan Dayah pada masa sekarang. ${ }^{18}$

Pertama, Dayah pada masa sebelum perang, yaitu pada 1873. Pada masa ini Dayah meliputi pendidikan di meunasahmeunasah, rangkang, Dayah Teungku Chik sampai pada pendidikan al-jami'ah, seperti Masjid Raya Baiturrahman Banda Aceh. Keberadaan lembaga-lembaga seperti ini, dapat dilihat berbagai situs peninggalan sejarah, di antaranya Dayah teungku Awe Geutah di Peusangan, Dayah Teungku Chik di Tiro (syekh Saman), Dayah Teungku Chik Tanoh Abee di Seulimum, Dayah Teungku di Lamnyong, Dayah Lambhuek dan Dayah di Krueng Kalee.

Kedua, Dayah pada masa perjuangan, pada masa perjuangan ini (masa kolonial Belanda), setiap daerah (nanggroe) memiliki sekurang-kurangnya mempunyai sebuah Dayah, Belanda kemudian merubahnya menjadi landschap yang jumlahnya 129 buah. Dengan demikian jumlah Dayah diperkirakan berjumlah 129 buah. Dayah pada masa ini memegang peranan penting dalam pengerahan tenaga pejuang ke medan pertempuran, terutama dalam mengobarkan semangat melalui pembacaan hikayat Perang sabi di Dayah-dayah, rangkang, meunasah dan masjid. Di kala itu Aceh banyak kehilangan ulama-ulama besar dan kehilangan banyak sejumlah kitab-kitab besar dalam berbagai disiplin ilmu, baik yang ditulis oleh ulama Aceh sendiri maupun yang ditulis oleh ulama-ulama dari Timur Tengah.

Selain kehilangan di atas, Belanda juga mengontrol lembaga pendidikan apa saja yang berada di bawahnya. Mereka melarang mengajarkan beberapa mata pelajaran yang berhubungan dengan politik dan yang dianggap dapat

Seminar Appresiasi Pesantren di Aceh Persatuan Dayah Inshafuddin, 1987), hal. 7.

${ }^{18}$ Mashuri, Dinamika Sistem Pendidikan Islam Di Dayah, Jurnal Ilmiah DIDAKTIKA, Vol. 13, No. 2, 2013, hal. 263-267. 
memajukan kebudayaan ummat. Tinggallah ilmu-ilmu yang berhubungan dengan ibadah murni (utama) saja yaitu ilmu fiqh, tauhid dan tasawuf. Sedangkan bahasa Arab dan ilmu mantik hanya sebagai alat untuk mempertajam memahami ilmu fiqih.

Ketiga, Dayah pada masa Kemerdekaan, perkembangan Dayah --yang notabenenya swasta-- pada masa ini sangat tersaingi oleh dua lembaga yaitu sekolah dan madrasah. Di samping itu sifat dari pendidikan Dayah yang dimiliki secara individual oleh ulama dirasakan agak sulit dalam pembinaan secara terorganisir. Mungkin akibat faktor inilah kemudian para ulama dan pimpinan Dayah seluruh Aceh berkumpul di Seulimum Aceh Besar pada 1968, sehingga berhasil mendirikan sebuah organisasi Persatuan Dayah Inshafuddin, sebagai suatu organisasi yang bergerak dalam melestarikan dan mengembangkan pendidikan Dayah di Aceh.

Keempat, Dayah pada masa sekarang, secara singkat dapat disampaikan bahwa Dayah dewasa ini telah mengalami perkembangan, di samping Dayah-dayah model tradisional juga muncul Dayah-dayah model terpadu (modern), mulai dari tingkat Tsanawiyah (SMP), Aliyah (SMA) sampai membuka Perguruan Tinggi seperti STAI Aziziyah Samalanga.

\section{Dayah dan Masyarakat Aceh}

Di Aceh, gerakan sosial politik, penciptaan kohevisitas sosial, kelahiran, kematian, pemikiran, membuka usaha, bernazhar, sakit sampai dengan kehilangan sesuatu barang melibatkan Dayah dan Teungku ${ }^{19}$ Dayah sebagai pemimpin dan rujukan dalam prosesi dan realisasinya. Sejak dari dulu di Aceh, agama dan politiktidak mengalami pemisahan yang tegas, sehingga antara teungku Dayah sebagai ulama dan sultan sebagai pemimpin politik saling bersimbiosis dalam menjalankan pemerintaan, bahkan ketika pemimpin politik mengalami krisis mereka (teungku Dayah) tampil keruang

${ }^{19}$ Teungku merupakan panggilan masyarakat Aceh terhadap orang yang memiliki pemahaman agama, kalau dalam bahasa Indonesia sederajat dengan Ustadz. 
politik menggantikan peran yang terakhir dalam mempertahankan negara. ${ }^{20}$

Hubungan yang akrab antara Dayah dengan masyarakat, menempatkan Dayah sebagai bagian yang tidak terpisahkan dengan masyarakat Aceh. Disinilah karakter keberislaman mereka dibentuk, tempat anak-anak muda memperoleh status terhormat di masyarakatnya, tempat pengingatan bagi mereka yang merasa telah menjau dari ajaran-ajaran agama Islam, dan Teungku Dayah yang bertempat tinggal di Dayah adalah "Ibu" bagi masyarakat Aceh yang senantiasa melindungi dan mengarahkan mereka tidak hanya pada masalah-masalah keagamaan tetapi juga sosial-politik. Hal ini membuat keberadaaan mereka menjadi figur dan agen sosial yang sangat berwibawa dan menentukan dalam masyarakat Aceh. ${ }^{21}$

Berdasarkan kenyataan ada empat kegunaan Dayah dalam perjalanan sejarah bagi masyarakat Aceh, antara lain: ${ }^{22}$

a. Dayah Sebagai Pusat Belajar Agama dan Cendikiawan.

Pada abad ke- 17, ketika masa Kerajaan Islam Aceh, Aceh menjadi pusat kegiatan Intelektual. Selama abad ini, beberapa sarjana dari negara lain datang untuk belajar ke Aceh. Seorang ulama terkenal Syekh Muhammad alMakkasari (1626-1699), salah seorang ulama tersohor di waktunya itu di kepulauan Melayu, pernah belajar di Aceh. Syekh Burhanuddin dari Minangkabau yang kemudian menjadi ulama terkenal dan menyebarkan Islam di Ulakan mendirikan surau di Minangkabau, juga pernah belajar di Aceh dibawah bimbingan Syekh 'Abd al-Rauf al-Singkili.

Pada masa selanjutnya, ketika terjadi kemunduran dalam bidang ekonomi dan politik di kesultanan Aceh, perhatian ulama Aceh dengan ilmu-ilmu agama tidak berkurang. Dayah melanjutkan memenuhi kebutuhan masyarakat akan ilmu pengetahuan. Sebelum kedatangan Belanda, Dayah-dayah di Aceh masih sering dikunjungi

${ }^{20}$ Nirzalin, Krisis Agensi Politik Teungku Dayah di Aceh, Ringkasan Desertasi (Yogyakarta: FISIPOL UGM, 2011), hal. 13.

${ }^{21}$ Ibid.

${ }^{22}$ Hasbi Amiruddin, Ulama Dayah: Pengawal Agama Masyarakat Aceh (Lhokseumawe: Nadiya, 2007), hal. 58. 
oleh masyarakat dari luar Aceh. Daud al-Fatani dari Pattani (sekarang satu wilayah di Thailand) yang kemudian dikenal sebagai ulama terkemuka, murid Muslim dari Asia Tenggara di Mekkah juga pernah mengunjungi Aceh sekitar tahun 1760-an. Dia belajar di Aceh selama dua tahun dengan Muhammad Zain al-Faqih Jalal al-Din al-Ashi.

\section{b. Peran Dayah dalam Melawan Penetrasi Penjajah}

Ketika Belanda ke Aceh, terdapat beberapa Dayah yang telah berdiri di kawasan tersebut. Ketika Perang meletus, Dayah memainkan peranan penting dalam perlawanan rakyat Aceh. Sebagaimana telah dipaparkan pada bab pertama, sultan dan para uleebalang tidak sanggup menjalankan kepemimpinan, jadi para tentara ingin pemimpin lain untuk melanjutkan perlawanan dalam rangka mempertahankan tanah air mereka. Hal ini menunjukkan bahwa Dayah, apa pun bentuk namanya ditempat lain, telah menjadi pusat perlawanan dalam menghadapi penetrasi penjajah. Hal serupa juga terdapat di Pattani, Thailand, zawiyah menjadi pusat latihan bagi para kesatria untuk mencapai kemerdekaan.

Apa yang terdapat dalam Hikayat Prang Sabi, yang menjadi suatu kekuatan yang membangkitkan semangat rakyat Aceh terjun keperang suci untuk mempertahankan tanah Aceh merupakan Salah satu indikasi lain yang menjelaskan keterlibatan ulama Dayah dalam perang ini. Dalam konteks ini, indikasi pertama mcnyatakan bahwa Hikayat Prang Sabi disusun dalam bahasa Aceh yang sering dipakai oleh ulama Dayah. Dalam hal ini, dalam satu Dayah biasanya dipakai tiga bahasa, yaitu bahasa Aceh, Melayu, dan Arab.

c. Dayah Sebagai Agen Pembangunan

Dayah telah banyak mengabdi kepada rakyat Aceh terutama dalam hal menghasilkan pemimpin masyarakat dalam bidang ilrnu pengetahuan agama. Orang-orang tersebut telah memainkan peran yang penting dalam membina komunitasnya dalam bidang keyakinan dan praktik agama. Meskipun demikian, Dayah juga mendapatkan kritik oleh para intelektual karena hanya 
menghasilkan lulusan dalam bidang agama dan tidak ada keahlian lain yang berguna.

Beberapa Dayah mencoba untuk mengajarkan berbagai keahlian bagi murid mereka. Bagaimanapun, inisiatif ini masih berada pada tahap terbatas. Beberapa program tidak diatur dengan baik, bahkan rada insidental, dan jenis keahlian yang dilatih pun masih tergantung pada tenaga pengajar yang tersedia. Pada bagian lain, beberapa lulusan Dayah menjadi pemimpin formal yang duduk di kursi pemerintahan; di lain pihak ada juga yang menjadi pemimpin informal. Biasanya mereka aktif dalam pembangunan masyarakat. Tradisi ini berlangsung sampai hari ini, meskipun lulusan dari lembaga pendidikan lain (madrasah dan lembaga pendidikan umum) juga aktif dalam kehidupan masyarakat.

d. Dayah sebagai Lembaga pendidikan bagi Masyarakat

Belajar di Dayah tidak membutuhkan banyak uang. Inilah yang menjadi faktor penting bagi masyarakat yang secara ekonomi tidak mampu. Rakyat bisa belajar di Dayah meskipun sangat miskin. Umumnya, Dayah-Dayah tidak membebankan murid-murid untuk membayar uang pendidikan.

Bagi murid yang fakir miskin, Dayah dengan sendirinya menyediakan makan, yang oleh Teungku (pimpinan Dayah) atau dari masyarakat selalu siap membantu. Dewasa ini, jika beberapa Dayah meminta biaya pendidikan biasanya tidak terlalu banyak. Murid-murid yang tidak punya uang biasanya bekerja di sawah atau kebun milik Dayah atau tinggal di tetangga-tetangga Dayah.

\section{Simbiosis Mutualisme Dayah dan Pemerintah}

Setiap Dayah yang didalamnya ada Teungku atau Ulama, jelas sebagai pusat pertumbuhan dan pengetahuan Islam. Tapi bagaimanapun, lembaga Dayah juga merupakan tempat 
komunikasi sosial bahkan kadang kala juga menjadi lembaga kontrol sosial terhadap kekuasaan.

Dilihat dari sejarah dan peranannya, ternyata Dayah mengambil peran yang sangat signifikan dalam membangun Aceh, bahkan negara ini. Betapa tidak, perjuangan bangsa ini dalam memerdekakan negara ini pada ummnya dimulai/berangkat dari Dayah (Khusus Aceh), dari sanalah semangat perjuangan berkobar untuk mengusir penjajah. Maka sangatlah wajar jika pemerintah sekarang baik pusat maupun daerah memperhatikan secara "spesial" pendidikan Dayah.

Pemerintah Aceh satu provinsi di Indonesia yang mengurusi pendidikan pesantren (Dayah), yang dikendalikan oleh Badan Pendidikan dan Pembinaan Dayah (BPPD) Provinsi atau Kabupaten/Kota. Sedangkan pendidikan umum (SLTA/MA) dikendalikan oleh Dinas Pendidikan Provinsi atau Kabupaten/Kota. Saat pendidikan umum mengalami degradasi, Pemerintah Aceh di bawah kepemimpinan Zaini-Muzakkir memiliki peluang untuk memperkuat dan mengawal pendidikan di Aceh melalui pendekatan pendidikan Dayah.

Pendidikan Dayah harus diperkuat dari segi administrasi organisasi secara menyeluruh. Pelibatan masyarakat harus benar-benar didukung dalam upaya eksistensi pendidikan Dayah di Aceh. Pendidikan Dayah di Aceh memiliki peluang menjadi jalur pendidikan alternatif setelah pendidikan umum terbukti gagal dalam memproduksi manusia-manusia yang cerdas dalam segala hal. Namun, peluang menjadikan pendidikan Dayah sebagai pendidikan alternatif belum direspons secara bijak oleh pemerintah. Hal ini terbukti bahwa pendidikan Dayah di Aceh tidak ada grand desain.

Program intervensi terhadap eksistensi pendidikan Dayah, malah kalau diteliti lebih jauh malah menjadikan pendidikan Dayah sebagai pendidikan sub ordinat. Di mana pada akhirnya menjadikan pendidikan Dayah tidak jauh berbeda dengan pendidikan umum di Aceh. Sebagai bukti, bahwa tidak ada grand desain pendidikan Dayah di Aceh, berikut saya

${ }^{23}$ Hasbi Amiruddin, Menatap Masa Depan Dayah di Aceh (Yogyakarta: Polydoor, 2009), hal. 104. 
tampilkan beberapa catatan menyangkut program yang pernah dilakukan pemerintah Aceh terhadap pendidikan Dayah: ${ }^{24}$

Pertama, tentang kebijakan klasifikasi Dayah. Melalui serangkai keputusan gubernur (Pergub) pada 2003, periode Abdullah Puteh, kemudian diperbaharui oleh Irwandi Yusuf melalui intruksinya pada tahun 2008 dimana salah satu poinnya adalah untuk melakukan klasifikasi pendidikan Dayah di Aceh secara komprehensif dan profesional melalui tipikal Dayah bertipe $\mathrm{A}, \mathrm{B}, \mathrm{C}$ dan nontipe ${ }^{25}$. Fase inilah cikal bakal awal intervensi pendidikan Dayah oleh Pemerintah Aceh.

Kedua, menyangkut dengan registrasi jumlah Dayah. Kebijakan ini juga melalui Pergub No.451.2/474/2003. Poin yang utama adalah registrasi Dayah dilakukan setiap tiga tahun sekali, melalui dana dari APBD. Pada 2008 juga hal serupa dilakukan untuk penggunaan anggaran kepada pembangunan sarana dan prasarana Dayah melalui instruksi Gubernur yang dijalankan oleh BPPD dengan kewajiban melakukan koordinasi dengan dinas-dinas teknis terkait.

Ketiga, menyangkut kebijakan pemberian bantuan kepada Dayah. Pada 2003-2007 pemberian bantuan kepada Dayah dilakukan oleh Dinas Pendidikan Provinsi, melalui Subdin Dayah. Pada 2008 wewenang itu menjadi milik BPPD Aceh berdasarkan Qanun No.5 Tahun 2007. Kemudian keluar instruksi Gubernur Irwandi Yusuf, No.03/INSTR/2008 yang ditujukan kepada BPPD Provinsi, tentang petunjuk teknis pelaksanaan pembangunan dan pengembangan sarana dan prasarana Dayah/pesantren, menyebutkan bahwa pemberian bantuan dan pengembangan dengan sistem kerja sama dan mengutamakan kepentingan santri dan masyarakat sekitar Dayah. Jenis bantuan yang diberikan, meliputi pembangunan musallah, asrama, masjid, wc, dan bangunan utama pengajian.

${ }^{24}$ Mukhlisuddin, Harian Serambi Indondesia, 23/7/2013.

${ }^{25}$ Tipikel Dayah didasari oleh beberapa indikator antara lain status tanah, kurikulum, sarana dan prasarana, tenaga kependidikan, santri, dan financial. Dimana ketentuan tipikel Dayah akan diputuskan dalam rapat BPPDA. Tipikel Dayah ini salah satunya akan berimbas kepada jumlah bantuan yang akan diberikan oleh pemerintah Aceh. 
Ada beberapa program jangka pendek yang dilakukan Pemerintah seperti pelatihan komputer untuk santri Dayah, pelatihan life skill santriwati (konveksi), pelatihan life skill satriwan (reparasi elektronik), bantuan untuk kegiatan ekstra kurikuler santri, musabaqah qirawatil kutub dan sayembara baca kita kuning, pelatihan jurnalistik santri serta pembinaan dan pengembangan kurikulum Dayah.

Program-program yang telah dirancang tersebut diharapkan dapat mendongkrak peningkatan kualitas pendidikan Dayah di Aceh melalui BPPDA, baik sumber daya manusia guru Dayah dan juga santrinya, upaya ini ditempuh karena seiring dengan timbuhnya kesadaran masyarakat tentang pentingnya peranan pendidikan agama dalam membentuk prilaku manusia, terutama genarasi muda. Disamping itu juga sekarang pihak Dayah telah membuka diri untuk menerima perubahan dan perbaikan untuk kemajuan dari institusi Dayah sendiri, banyak program yang digulirkan diikuti oleh pihak Dayah dengan serius.

Gayung telah bersambut, kebijakan pemerintah yang menghapus diskriminasi Dayah sudah diterbitkan, sementara Dayah sendiri sudah siap untuk mengembangkan diri, tinggal bagaimana mengisi peluang itu dengan kerja nyata demi kemajuan pendidikan di masa yang akan datang.

\section{Landasan Hukum, Tugas, Fungsi, dan Kewenangan BPPDA}

Badan Pembinaan Pendidikan Dayah (BPPD) Aceh berdiri pada tahun 2008. Badan Pembinaan Dayah ini memiliki tugas pokok melakukan pembinaan terhadap Dayah-Dayah yang ada di Aceh. Dasar pembentukan badan ini berdasarkan Undang-Undang Pemerintahan Aceh (UUPA) No. 11 Tahun 2006, Qanun No. 5 Tahun 2007 Tentang Susunan Organisasi dan Tata Kerja Dinas, Lembaga Teknis Daerah dan Lembaga Daerah Provinsi Nanggroe Aceh Darussalam, serta Qanun Nomor 5 Tahun 2008 tentang Penyelenggaraan Pendidikan di Aceh. $^{26}$

26 http://www.peristiwa.co/sejarah-pembentukan-badan-pembinaanpendidikan-Dayah-aceh.html, diakses tanggal, 10 Juni 2014. 
Badan ini juga bekerja secara maksimal untuk meningkatkan mutu dan kualitas Dayah, baik prasarana, kurikulum Dayah, membantu merubah manajemen Dayah dan peningkatan kualitas santri serta memberdayakan Dayah sesuai dengan letak geografis Dayah. Badan ini memiliki beberapa program prioritas seperti pembentukan dan pengembangan Ma'had 'Ali, akreditasi Dayah, peningkatan profesionalisme manajemen Dayah; dan peningkatan kompetensi guru. Kehadiran lembaga ini di sambut dengan sangat senang oleh abu-abu Dayah. Pasalnya, sebelum BPPD dibentuk, Dayah termarginalisasi, baik secara fungsional dimana Dayah terkesan masih sangat tradisional maupun secara struktural, dimana Dayah kurang mendapat perhatian dari pemerintah.

Sesuai Qanun Aceh Nomor: 5 Tahun 2007 tentang Struktur Organisasi dan Tata Kerja Dinas, Lembaga Tehnis Daerah, Lembaga Daerah Provinsi Nanggroe Aceh Darussalam, bahwa Tugas Pokok, Fungsi dan Kewenangan Badan Pembinaan Pendidikan Dayah Aceh adalah sebagai berikut: ${ }^{27}$

a. Tugas Pokok BPPD Aceh adalah:

1) Pembinaan teknis pendidikan dan pengajaran.

2) Pelaksanaan fasilitasi usaha ekonomi produktif.

3) Pelaksanaan fasilitasi kesejahteraan tenaga pengajar.

4) Pelaksanaan peningkatan kualitas sumber daya santri.

5) Pemantauan, evaluasi dan pelaporan penyelenggaraan pembinaan pendidikan Dayah.

6) Pembinaan unit pelaksana teknis badan (UPTB).

b. Fungsi BPPD Aceh adalah:

1) Pelaksanaan urusan ketata-usahaan badan.

2) Penyusunan program kerja tahunan, jangka menengah dan jangka panjang.

3) Penyusunan kebijakan teknis di bidang pembinaan pendidikan Dayah.

4) Pemberian perizinan dan pelaksanaan pelayanan umum di bidang pembinaan pendidikan Dayah.

5) Penyiapan rancangan qanun dan produk hukum di bidang penyelenggaraan pembinaan pendidikan Dayah.

${ }^{27}$ Ibid. 
c. Kewenangan BPPD Aceh adalah:

1) Mengembangkan dan mengatur berbagai jenis, jalur dan jenjang pendidikan Dayah serta menambah materi muatan lokal.

2) Mengembangkan dan mengatur lembaga pendidikan Dayah.

3) Menetapkan kebijakan tentang penerimaan santri dari masyarakat minoritas, terbelakang dan atau tidak mampu.

4) Menyediakan bantuan pengadaan buku pelajaran pokok/modul pendidikan Dayah.

5) Membantu penyelenggaraan Dayah yang meliputi pembinaan kurikulum, akreditasi dan fasilitasi kesejahteraan tenaga pengajar.

6) Menyelenggarakan pelatihan, penataran dan kerja sama dalam rangka peningkatan kualitas tenaga pengajar.

7) Melaksanakan pendidikan dan pelatihan di bidang pendidikan dan pengajaran Dayah.

8) Melakukan inventarisasi aset dan keberadaan lembaga Dayah.

9) Mengalokasikan sumber daya manusia pontensial di bidang pendidikan Dayah.

\section{Problematika Pengakreditasian Dayah}

Kalangan ulama menolak rencana Pemerintah Provinsi Aceh untuk mengakreditasi (pengakuan status) bagi Pondok Pesantren (Ponpes/Dayah) jika dilakukan tanpa melibatkan para ulama setempat. Kami menolak akredasi sepihak jika pemerintah tidak melibatkan ulama untuk menentukan kriteria Ponpes/Dayah yang akan dilakukan Dinas Pendidikan Provinsi Aceh, kata Sekretaris Himpunan Ulama Dayah Aceh (HUDA) Tgk Faisal Ali, di Banda Aceh. ${ }^{28}$ Sebelumnya, Wakil gubernur Muhammad Nazar menyatakan akan mengagredasi sebanyak 1.167 buah Dayah di seluruh Aceh.

Faisal Aly menyatakan pihaknya tidak menolak akredasi lembaga pendidikan agama (Dayah) yang akan dilakukan

${ }^{28}$ Harian Umum PELITA, edisi Rabu, 29/8/2008. 
Pemerintah melalui lembaga independen, tapi harus ada keterlibatan aktif para ulama dan pimpinan Ponpes didalamnya. Karena, tambah dia, yang lebih tahu kondisi dan masalah intern Ponpes/Dayah itu adalah ulama dan para pimpinan lembaga pendidikan agama (Islam) sendiri. Kalau ulama tidak dilibatkan di dalam proses akredasi maka sangat dikhawatirkan terjadi penilaian yang salah terhadap Dayah/Ponpes itu sendiri. ${ }^{29}$

Namun semangat juang yang luar biasa dari para santri Dayah masih direspon dingin oleh dunia kerja, ribuan lembar ijazah yang dikeluarkan Dayah di Aceh belum diterima oleh lapangan kerja, sangat disayangkan setelah bertahun-tahun menuntut ilmu tidak mendapat pengakuan berarti dari pihak terkait, sehingga menjadi dilema baru bagi intelektual Dayah tersebut, malah untuk melanjutkan kuliah saja belum semua perguruan tinggi menerimanya, ini memang kontra produktif sehingga berbagai pihak harus mencari solusinya.

Akreditasi merupakan salah satu penyebabnya, sehingga upaya untuk mengakreditasi Dayah hendaklah dilakukan secara cepat dan serius dengan melibatkan berbagai pihak supaya tidak menjadi masalah di kemudian hari. Proses akreditasi tersebut akan menjadikan Dayah setara dengan pendidikan umum lainnya, sehingga persoalan diskriminasi ijazah tidak lagi terjadi. Pihak Dayah sendiri pada prinsipnya siap menyahuti proses tersebut selama tidak menghilangkan ciri khas mereka sendiri, hal itu sebagaimana diungkapkan Waled Hasanoel Bashry HG, Pimpinan Dayah MUDI MESRA kepada santunan: ${ }^{30}$

"Kalau konsep yang telah kami buat ini disetujui oleh pemerintah, hal tersebut mungkin bisa-bisa saja. Ini harus terlebih dahulu kita sepakati bersama. Tapi kalau hanya sepihak saja dari pemerintah yang menyebabkan hilangnya kekhasan Dayah itu tersendiri, ini tidak dapat kita penuhi, ini tidak dapat kita pertanggungjawabkan kepada masyarakat nantinya"

\section{${ }^{29}$ Ibid.}

${ }^{30}$ Mulyadi Nurdin, Sejarah Baru Dayah, Majalah Santunan, Ed. 6, Juli 2010, hal. 7 . 
Akreditasi itu sendiri akan mengarah kepada standarisasi mutu dan kurikulum Dayah itu sendiri supaya ada keseragaman, tidak berjalan sendiri-sendiri, adanya kejelasan antara Dayah, diniyah, TPA dan lain-lain, kalau perlu adanya SK tersendiri dari lembaga pemerintah supaya tidak membingungkan masyarakat.

\section{Kesimpulan}

Eksistensi Dayah tidak bisa dilepaskan dari peran negara. Ranah kultural yang digeluti Dayah selama ini menjadi landasan yang sangat berarti bagi eksistensi negara khususnya daerah Aceh. Perjuangan Dayah baik secara fisik maupun secara kultural tidak bisa dihapus dari catatan sejarah Aceh. Dan kini generasi santri tersebut mulai memasuki jabatan-jabatan publik (pemerintah), baik eksekutif maupun legislatif yang dulunya hanya sebatas mimpi.

Landasan kultural yang ditanamkan kuat di Dayah diharapkan menjadi guidence dalam implementasi berbagai tugas baik pada ranah sosial, ekonomi, hukum, maupun politik. Baik di lembaga pemerintahan maupun swasta yang konsisten, transparan, dan akuntabel. Kalau selama ini Dayah telah menyumbangkan seluruh dayanya untuk kepentingan masyarakat, maka harus ada simbiosis mutualisme antara keduanya. Sudah waktunya pemerintah memberikan perhatian serius atas kelangsungan Dayah. Kalau selama ini Dayah bisa eksis dengan swadaya, maka eksistensi tersebut akan lebih maksimal apabila didukung oleh pemerintah dengan serius. Badan Dayah yang kini ada Aceh (BPPDA), bukan hanya sekadar menambah SKPA di jajaran Pemerintah Aceh, melainkan harus benar-benar menjalankan tugas dan fungsinya dalam memajukan Dayah-Dayah yang ada di daerah ini.

Oleh sebab itu, diperlukan revitalisasi relasi antara Dayah dan pemerintah yang selama ini berjalan apa adanya. Tapi di sini perlu digaris bawahi bahwa revitalisasi relasi antara pemerintah dan Dayah adalah relasi yang sebenarnya, bukan relasi yang hanya kepentingan waktu pilkada dan pemilu saja, yang berlomba-lomba mendatangi Dayah, mendekati pimpinan Dayah agar mulus perjalanannya menuju apa yang diinginkan, 
dan bahkan supaya mulus untuk duduk di periode selanjutnya. Atau sebaliknya dari unsur pimpinan Dayah sendiri atau dari kalangan Dayah yang membawa nama Dayah untuk menuju kepentingan kelompok dan pribadi demi ambisi meraih kekuasaan.

\section{Saran}

Dari serangkaian penjelasan diatas, ada tiga elemen yang saling keterikatan dalam menjaga eksistensi, stabilitas dan prospek lembaga pendidikan tertua di Aceh, yaitu :

a. Dayah. Dengan kondisi atmosfir Pemerintah Aceh yang telah membuka keran untuk Dayah dan kontrol sosial dari masyarakat, maka dalam hal ini Dayah harus memanfaatkan momen ini untuk terus membenah diri dari berbagai aspek, agar cita-cita Dayah untuk menjadi lembaga formal dari tingkat ibtidaiyah sampai perguruan tinggi akan terwujud.

b. Masyarakat. Dayah yang sudah mulai bangkit dengan "perjuangannya", masyarakat harus terus menerus memberikan dukungan sesuai dengan kemampuannya, baik materiil maupun spiritual, dan sekaligus menjadi kontrol sosial. Karena tanpa adanya masyarakat mustahil Dayah bisa berkembang dengan baik.

c. Pemerintah. Dayah yang merupakan warisan masyarakat Aceh, pemerintah Aceh yang menjadi salah satu komponen yang bertanggung jawab menjaga kelestariannya, harus tetap menjaga warisan ini dengan melakukan berbagai usaha agar Dayah tidak hilang ditelan derasnya arus globalisasi. Pemerintah yang telah memberikan perhatian terhadap Dayah agar terus ditingkatkan untuk masa yang akan datang, mulai dari masalah kurikulum, sarana dan prasarana, sampai kepada tingkat kerjasama dengan lembaga-lembaga pendidikan di luar negeri. Diharapkan kedepan dengan usaha yang dilakukan oleh Pemerintah dan juga elemen-elemen yang lain, Dayah akan menjadi lembaga pendidikan yang unik di Indonesia bahkan di mancanegara. 


\section{DAFTAR PUSTAKA}

Almuhajir, Manajemen Dayah: Realita, Problematika, dan Citacita, Jurnal TRIBAKTI, Vol. 23, No. 2, 2012.

Amiruddin, Hasbi, Ulama Dayah: Pengawal Agama Masyarakat Aceh, Lhokseumawe: Nadiya, 2007.

Menatap Masa Depan Dayah di Aceh, Yogyakarta: Polydoor, 2009.

Dhuhri, Saifuddin, DAYAH DALAM TIGA PHASE PERKEMBANGAN (Menelaah Pendidikan Berbasis Perubahan Sosial yang telah Punah), Jurnal SARWAH, Vol, IX, No. 1, 2011.

Edward Steven and George H. Wood, Justice, Idiologi, And Education: An Introduction To The Social Fundation Of Education, New York: Random House, 1987.

Harian Umum PELITA, edisi rabu, 29/8/2008.

Harian Serambi Indonesia, edisi, selasa, 23/7/2013.

Haspy, Mohd. Basyah, Appresiasi terhadap Tradisi Dayah: Suatu Tinjauan terhadap Tata Krama dan Kehidupan Dayah, Banda Aceh: Panitia Seminar Appresiasi Pesantren di Aceh Persatuan Dayah Inshafuddin, 1987.

Hurgronje, C. Snouck, The Atjehnese, A.W.S. O'Sullivan (terj.), Vol.I, Leiden: J.Brill, 1906.

Latif, Hamdiah M., Tradisi dan Vitalitas Dayah (Kesempatan dan Tantangan), Jurnal Imliah DIDAKTIKA, Vol.8, No.2, 2007.

Mashuri, Dinamika Sistem Pendidikan Islam Di Dayah, Jurnal Ilmiah DIDAKTIKA, Vol. 13, No. 2, 2013. 
Mulyadi Nurdin, Sejarah Baru Dayah, Majalah Santunan, Ed. 6, Juli 2010.

Nirzalin, Krisis Agensi Politik Teungku Dayah di Aceh, Ringkasan Desertasi, Yogyakarta: FISIPOL UGM, 2011.

Rohman, Arif, Politik Ideologi Pendidikan, Yogyakarta:

LaksBang Mediatama, 2009.

Rusdi Sufi dan Agus Budi Wibowo, Pendidikan Di Aceh dari Masa ke Masa, Banda Aceh: Badan Perpustakaan Provinsi NAD, 2009.

Siegel, James, The Rope of God, Los Angeles: University of California Press, 1969.

Sufi, Rusdi, Tgk. Hasan Krueng Kalee dan Teuku Nyak Arief, Profil Ulama dan Umara Aceh, Banda Aceh: Badan Perpustakaan Provinsi NAD, 2006.

Sirozi, Muhammad, Politik Pendidikan, Jakarta: Raja Grafindo Persada, 2010.

http://aceh.tribunnews.com/2013/07/23/mengawal-pendidikanDayah, diakses tanggal 12 Juni 2014.

http://bangun-aceh.blogspot.com/2012/09/tentara-dari-alumniDayah-mengapa-tidak.html, diakses tanggal 12 Juni 2014.

http://www.peristiwa.co/sejarah-pembentukan-badanpembinaan-pendidikan-Dayah-aceh.html, diakses tanggal, 10 Juni 2014. 